the production of dripping, sausages, skins, tripe and calves' feet, tallow, meat meal, blood manure, and animal glands for medicinal purposes. In conclusion, the Committee suggests that the difficulties of adjusting the slaughtering charges and the prices of byproducts retained at the abattoir for processing might be minimised by leasing the abattoirs to slaughtering and by-product companies or associations. The local authority would thus be relieved of the difficulty of fixing service charges and yet could reserve to itself the right of general supervision.

\section{Generic Names of British Insects}

UNDER this title, the Council of the Royal Entomological Society of London has decided to issue, in parts as completed, a work designed to promote stability in the use of scientific nomenclature as applied to the insects of Great Britain. The scheme has been entrusted to a Committee on Generic Nomenclature, under the chairmanship of Sir Guy Marshall, with the assistance of the entomologists at the British Museum (Natural History). The terms of reference involve the preparation of "lists of scientific names to be fixed as genotypes of genera of British insects with a view to the suspension where necessary of the law of priority in respect of those generic names". The separate orders of insects are being dealt with by small panels of specialists acting as sub-committees of the central committee. The first list of generic names to be published under this scheme is entitled "The Generic Names of the British Rhopalocera with a Check List of the Species" (Feb. 1934) by Mr. Francis Hemming, and is to be ob. tained, price $3 s$. 6d., from the Society at 41, Queen's Gate, S.W.7. In this publication, the authority for fixing the genotype is given in each case, followed by the chief synonyms and the accepted names of the British species, for each genus concerned. There follow, wherever necessary, notes on special questions of nomenclature that may arise. In the case of four generic names, namely, Argynnis, Vanessa, Strymon and Colias, it is contended that the strict application of the rules of nomenclature should be suspended since, otherwise, it would involve the disturbance of these long-established names to no real advantage. The whole undertaking should prove a useful guide to all entomologists and a strong incentive towards the attainment of uniformity.

\section{Value of Experiments on Animals}

THE eighth Stephen Paget Memorial Lecture of the Research Defence Society, on "Experiments on Man", delivered by Prof. J. Bareroft, appears in The Fight against Disease, No. 3, 1934. The question whether the results of experiments performed on animals can be regarded as being applicable to man is discussed. It is concluded that in a great many cases the relevant information can be obtained from animal experiments. In certain instances, it may be necessary to perform the experiments on man, as in the elucidation of sensation and mental performances, and in the communication of disease when animals are unaffected by the virus. Attention is directed by the treasurer to the need for increased financial support for the Society.

\section{Announcements}

The Trustees of Herbert Spencer have in the Press a book by Dr. J. Rumney on sociology, giving an account of the part Spencer played in founding the science, and showing to what extent his views have guided later scholars. The book will be published by Messrs. Williams and Norgate, Ltd., in the early autumn.

AT the annual general meeting of the Lister Institute of Preventive Medicine, held on May 30, the governing body presented the Institute's fortieth annual report. In addition to items concerning administration and finance, the Report gives a survey and summary of the scientific work carried out in the various departments during the year, forming a record of much valuable research. The Institute also houses the National Collection of Type Cultures, a collection of authenticated cultures of bacteria and fungi, which are available for those who may require them.

The British Federation of University Women, Crosby Hall, Cheyne Walk, S.W.3, has issued and published a revised and enlarged second edition of "A List of International Fellowships for Research" (Price 2s.). The purpose of the book is to provide both men and women graduate students and research workers in nearly all countries with information concerning the opportunities open to them for carrying on their work in other countries by means of travelling fellowships or scholarships. Most of the fellowships listed are open equally to men and women, but those restricted to either sex are distinctively marked.

Applications are invited for the following appointments, on or before the dates mentioned :-A lecturer in mining at the Chesterfield Technical College-The Clerk to the Governors, Technical College, Chesterfield (Sept. 24). A chief lecturer in electrical engineering at the West Ham Municipal College, Romford Road, Stratford, E.15-The Principal (Sept. 27). A chief veterinary officer for the North Riding of Yorkshire County Council--The Clerk to the County Council, County Hall, Northallerton, Yorks (Oct. 1). A resident tutor in physics and mathematics at Borough Road College, Isleworth, Middlesex-The Principal. An assistant lecturer in education (especially in science subjects) at University College, Exeter-The Registrar.

Erratum. By a regrettable mistake, the Hardy Memorial Lecture at Aberdeen was referred to in early issues of NaTURE of September 15, p. 411, as having been delivered by Sir Frank Heath. The lecture was, of course, given by Sir Frank Smith, whose name appears correctly in later issues, 